\title{
Oxygen limitation of thermal tolerance in cod, Gadus morhua L., studied by magnetic resonance imaging and on-line venous oxygen monitoring
}

\author{
Gisela Lannig, Christian Bock, Franz J. Sartoris, and Hans O. Pörtner \\ Alfred Wegener Institute for Marine and Polar Research, 27568 Bremerhaven, Germany \\ Submitted 8 December 2003; accepted in final form 11 June 2004
}

Lannig, Gisela, Christian Bock, Franz J. Sartoris, and Hans O. Pörtner. Oxygen limitation of thermal tolerance in cod, Gadus morhua L., studied by magnetic resonance imaging and on-line venous oxygen monitoring. Am J Physiol Regul Integr Comp Physiol 287: R902-R910, 2004. First published June 17, 2004; 10.1152/ ajpregu.00700.2003.-The hypothesis of an oxygen-limited thermal tolerance due to restrictions in cardiovascular performance at extreme temperatures was tested in Atlantic cod, Gadus morhua (North Sea). Heart rate, changes in arterial and venous blood flow, and venous oxygen tensions were determined during an acute temperature change to define pejus ("getting worse") temperatures that border the thermal optimum range. An exponential increase in heart rate occurred between 2 and $16^{\circ} \mathrm{C}\left(\mathrm{Q}_{10}=2.38 \pm 0.35\right)$. Thermal sensitivity was reduced beyond $16^{\circ} \mathrm{C}$ when cardiac arrhythmia became visible. Flowweighted magnetic resonance imaging (MRI) measurements of temperature-dependent blood flow revealed no exponential but a hyperbolic increase of blood flow with a moderate linear increase at temperatures $>4{ }^{\circ} \mathrm{C}$. Therefore, temperature-dependent heart rate increments are not mirrored by similar increments in blood flow. Venous $\mathrm{PO}_{2}\left(\mathrm{Pv}_{\mathrm{O}_{2}}\right)$, which reflects the quality of oxygen supply to the heart of cod (no coronary circulation present), followed an inverse U-shaped curve with highest $\mathrm{Pv}_{\mathrm{O}_{2}}$ levels at $5.0 \pm 0.2^{\circ} \mathrm{C}$. Thermal limitation of circulatory performance in cod set in below $2^{\circ} \mathrm{C}$ and beyond $7^{\circ} \mathrm{C}$, respectively, characterized by decreased $\mathrm{Pv}_{\mathrm{O}_{2}}$. Further warming led to a sharp drop in $\mathrm{Pv}_{\mathrm{O}_{2}}$ beyond $16.1 \pm 1.2^{\circ} \mathrm{C}$ in accordance with the onset of cardiac arrhythmia and, likely, the critical temperature. In conclusion, progressive cooling or warming brings cod from a temperature range of optimum cardiac performance into a pejus range, when aerobic scope falls before critical temperatures are reached. These patterns might cause a shift in the geographical distribution of cod with global warming.

in vivo magnetic resonance imagine; venous oxygen partial pressure; heart rate; blood flow

RECENTLY, A NORTHWARD SHIFT of North Sea cod populations due to warming was suggested to be linked to the thermal physiology of the animals (31), with a species- and populationspecific pattern of oxygen-limited thermal tolerance that has been elaborated as a general feature in animal organisms (29). Among marine invertebrates and fish, evidence for oxygenlimited thermal tolerance first arose from observations of lowand high-temperature thresholds termed critical temperatures $\left(\mathrm{T}_{\mathrm{c}}\right)$, which are associated with the transition to anaerobic mitochondrial metabolism (for review, see Ref. 29). Second, and within the envelope of $\mathrm{T}_{\mathrm{c}}$, thermal limitation occurs early by the onset of a limitation in whole animal aerobic scope at low and high pejus temperatures $\left(\mathrm{T}_{\mathrm{p}}\right.$; pejus means "getting worse"). Pejus values are set by limited capacities of oxygen

Address for reprint requests and other correspondence: H. O. Pörtner, Alfred Wegener Institute for Marine and Polar Research, 27568 Bremerhaven, Germany (E-mail: hpoertner@awi-bremerhaven.de). supply mechanisms, first seen in crustaceans as the onset of a decrease in arterial $\mathrm{Po}_{2}$ (Ref. 16; for review, see Refs. 29, 32, 34). Accordingly, thermal limitation in fish was interpreted as being caused first by limited oxygen supply capacity and second by transition to anaerobic metabolism (e.g., 23, 40).

The processes of thermal adaptation cause an optimization of whole animal aerobic scope and capacity to a limited thermal window $(30,31)$. Such optimization may be linked to behavioral preferences. For instance, Atlantic cod (Gadus morhua) from the northwest Atlantic react very sensitively to ambient temperature and follow a migration highway between 2 and $3^{\circ} \mathrm{C}$ as shown by Rose (36). Identifying the thermal optimum and the mechanisms behind will thus provide important information about the degree of thermal specialization of a species and the width of its thermal window in relation to biogeographical distribution.

While the limitation of both circulatory and ventilatory performance capacities appeared responsible for the onset of thermal stress in crustaceans (16), ventilation was affected later than circulation in fish (23). In rainbow trout, Salmo gairdneri, Heath and Hughes (20) found that heart rate $\left(f_{\mathrm{H}}\right)$ decreased at temperatures $>24^{\circ} \mathrm{C}$, whereas ventilation remained virtually unchanged until death of the animals occurred. More recently, Sartoris et al. (37) suggested that oxygen uptake via ventilation did not decrease with acute warming in cod, G. morhua; therefore, limited cardiac rather than ventilatory performance might be more crucial in the thermal limitation of fish. Unlike the mammalian heart, the oxygen supplied to the heart of cod, like the majority of fish, is provided by venous blood rather than a coronary circulation. Therefore, this discrepancy might be due to insufficient oxygen supply to the myocardium (11, 12). Accordingly, a drop in venous but not in arterial $\mathrm{Po}_{2}$ was observed in gill blood of resting cod during warming (37), reflecting progressive limitation of oxygen supply to the heart. This will likely affect the functional scope of the heart, e.g., during exercise. Farrell (12) concluded that in salmonid fish cardiac output during exercise reaches its maximum within an optimal temperature range. According to a recent model, an increase in temperature beyond such optimum would lead to increased oxygen demand by baseline metabolism, leaving less oxygen for cardiac scope. With cardiac circulation finally being deficient in oxygen, the heart becomes hypoxic and a reduction in functional capacity or scope results. Insufficient capacity of the circulatory system in fish would not only be the cause of unbalanced oxygen delivery and demand, but vice versa, i.e., circulatory organs may also be the first affected by limited aerobic scope, oxygen deficiency, anaerobiosis, and

The costs of publication of this article were defrayed in part by the payment of page charges. The article must therefore be hereby marked "advertisement" in accordance with 18 U.S.C. Section 1734 solely to indicate this fact. 
energetic failure at extreme temperatures (for review, see Ref. 30).

Consequently, we set out to analyze the range of thermal tolerance of Atlantic cod based on blood oxygen analyses and to apply the concept of oxygen-limited thermal tolerance and $\mathrm{T}_{\mathrm{p}} \mathrm{s}$ to this species. We investigated whether and how temperature-dependent cardiovascular performance might contribute to thermal limitation by measuring $f_{\mathrm{H}}$, arterial and venous blood flow, and venous $\mathrm{PO}_{2}\left(\mathrm{Pv}_{\mathrm{O}_{2}}\right)$ in the ductus Cuvier of cod, G. morhua, from the North Sea during acute temperature change. Thereby, it was possible for the first time to adequately characterize the window of thermal tolerance of this species as the window of aerobic performance in its natural environment.

\section{MATERIALS AND METHODS}

Animals and experimental protocol. Cod, G. morhua, of the southern North Sea (mean size, $48.3 \pm 5.3 \mathrm{~cm}$; mean mass, $847.2 \pm 251.1$ g) were caught by bottom trawling in the German Bight. Fish were kept in natural seawater (32\%o salinity) of $10 \pm 1^{\circ} \mathrm{C}$ under a controlled photoperiod (12:12-h: light-dark) for at least 4 wk. Cod were fed a diet of frozen mussels, Mytilus edulis, twice per week. Feeding was terminated $1 \mathrm{wk}$ before the start of experimentation.

Two experimental series were carried out. First, temperaturedependent $f_{\mathrm{H}}$ was recorded in fish catheterized in the afferent branchial artery, paralleled by measurements of blood flow with magnetic resonance imaging. In a second set of experiments, temperature-induced changes in $\mathrm{Pv}_{\mathrm{O}_{2}}$ in the ductus Cuvier were investigated using microoptodes (see Surgery and data collection procedures). After surgery the fish was placed in a Plexiglas flow-through chamber of $\sim 6$-liter volume (length $63 \mathrm{~cm}$; diameter $12 \mathrm{~cm}$ ). For recovery the fish was oriented toward the incoming water with a constant flow of aerated seawater at $2-3 \mathrm{l} / \mathrm{min}$ and $10^{\circ} \mathrm{C}$. Because MRI techniques applicable to marine animals like RARE and FLASH could not be used for these demersal fish without movement artefacts $(4,5)$, the fish was restrained by bails in a way that it was still able to move its tail and pectoral fins but large horizontal movements were prevented. This setup was also used for $\mathrm{Pv}_{\mathrm{O}_{2}}$ measurements in the second experimental series. In both series, temperature was changed by $1{ }^{\circ} \mathrm{C} / \mathrm{h}$. To monitor temperature, fluoroptic temperature sensors (Polytec) were installed in the tank reservoir as well as in the experimental chamber. Temperature was controlled to $\pm 0.1^{\circ} \mathrm{C}$ by means of cryostats.

The cod were left inside the experimental setup at $10^{\circ} \mathrm{C}$ for at least $24 \mathrm{~h}$ to recover from handling stress $(37)$. Data $\left(f_{\mathrm{H}}\right.$, blood flow, and $\mathrm{Pv}_{\mathrm{O}_{2}}$ ) were monitored immediately after surgery. After control measurements at $10^{\circ} \mathrm{C}$ (acclimation temperature), water temperature was decreased toward $1{ }^{\circ} \mathrm{C}$ by $1{ }^{\circ} \mathrm{C} / \mathrm{h}$. Afterward, the water was warmed to $10^{\circ} \mathrm{C}$ within $30 \mathrm{~min}$, and the cod were left to recover overnight. Temperature was increased to $19^{\circ} \mathrm{C}$ by $1^{\circ} \mathrm{C} / \mathrm{h}$ on the next day, when $f_{\mathrm{H}}$ in all cod had returned to control values. In contrast to $f_{\mathrm{H}}$ and blood flow analyses, measurements of $\mathrm{Pv}_{\mathrm{O}_{2}}$ were performed in different individuals during either temperature decrease or increase. In some cases and over time the microoptode implant became unstable due to movements of the fish. Therefore, the experimental period was limited to $48 \mathrm{~h}$ in general. At the end of the experiments, animals were anesthetized by the addition of $0.08 \mathrm{~g} / \mathrm{l}$ tricaine methanesulfonate (MS-222) to the system. The catheter or microoptode was gently removed (see Surgery and data collection procedures), and the fish were brought back into the aquarium. None of the fishes died, and all animals had resumed feeding by the next morning.

Surgery and data collection procedures. For all surgeries, cod were anesthetized with $0.08 \mathrm{~g} / \mathrm{l} \mathrm{MS-222}$ and weighed. Their body lengths were determined, and they were then transferred to an operating table. During surgery $(\sim 30 \mathrm{~min})$, gills were continuously perfused with aerated seawater $\left(8-10^{\circ} \mathrm{C}\right)$ containing $0.04 \mathrm{~g} / \mathrm{l} \mathrm{MS}-222$.
$f_{H}$. A polyethylene catheter (PE-50, $30 \mathrm{~cm}$ long), filled with heparinized $(50 \mathrm{IU} / \mathrm{ml}) \quad 0.9 \% \mathrm{NaCl}$ solution, was inserted into the afferent branchial artery of the last gill arch $(\sim 0.5 \mathrm{~cm})$, secured with skin suture, and fixed to the gill arch with cyanoacrylate glue. For better fixation, the catheter was also secured to the fish skin. After the cod was placed into the chamber, the catheter was connected to an 1.5-m-long PE-50 tubing, attached to a pressure transducer (UFI, Motro, Canada) that was connected to a bridge amplifier of a MacLab system (AD Instruments, Australia). Recordings were stored on a computer at a sampling rate of $10 \mathrm{~s}^{-1}$. Before the start of experimentation, daily calibration of the pressure transducer was performed against a static water column.

$P v_{O_{2}}$. For $\mathrm{Pv}_{\mathrm{O}_{2}}$ measurements an optode was implanted into the ductus Cuvier following a procedure modified from Farrell and Clutterham (13). Before insertion, the optode was calibrated in oxygen-free and air-saturated seawater, and the optode tip was soaked in a $100 \mathrm{IU} / \mathrm{ml}$ heparin solution. A dorsoventral incision was made in the left cleithrum to expose the ductus Cuvier. A PE-50 tubing $(\sim 2 \mathrm{~cm}$ long) was placed right in front of the ductus Cuvier, secured with a skin suture, and fixed with cyanoacrylate glue. Afterward, a small incision was made into the vein. The optode was passed through the fixed PE-50 tubing and advanced $\sim 1 \mathrm{~cm}$ retrograde into the ductus. The optode was then fixed to the PE-50 tubing with glue, and sutures were used to secure the optode to the cleithrum and the fish skin in front of the dorsal fin. In this way, changes in the position of the optode could be prevented for extended periods despite spontaneous fish movements.

Measurements were performed following the principles described by Sartoris et al. (37) using fiber-optic microoptodes (Pre Sens, Germany) connected to a computer (sampling rate: $1 \mathrm{~min}^{-1}$ ). Temperature corrections as described by Sartoris et al. (37) were not necessary because extended Tx-type optodes with integrated temperature compensation were used instead of Microx I-type optodes.

Blood flow. MRI for the determination of relative blood flow changes in different vessels was performed with a Snapshot FLASH sequence (18). Imaging parameters were as follows: matrix size, $128 \times 128$, resulting in an in-plane resolution of $470 \mu \mathrm{m}$; repetition time $=9 \mathrm{~ms}$, echo time $=3.1 \mathrm{~ms} ; 45^{\circ}-60^{\circ}$ hermite pulses; pulse length $2,000 \mu \mathrm{s}$; 1 slice, slice thickness $5 \mathrm{~mm}$; field of view, $6 \times 6 \mathrm{~cm}$; distance of center $-40 \mathrm{~mm}$; number of averages, 32; 10 dummy scans; total acquisition time, $32 \mathrm{~s}$. The need of signal averaging resulted in a temporal resolution of $\sim 30 \mathrm{~s}$ for blood flow analyses, yielding a mean value of flow during several heartbeats. Values might therefore underestimate peak blood flow, especially at pulses of higher $f_{\mathrm{H}}$. The analysis yields a relative parameter of flow in units of distance per time. Figure 1 presents a typical axial view of a flow-weighted magnetic resonance image from North Sea cod under control conditions. The faster Snapshot Flash method compared with classical flow-weighted Flash sequences in combination with the restriction of the bails (visible on the left side of Fig. 1) allowed the acquisition of magnetic resonance images without movement artefacts and sufficient signal-to-noise ratio. The aorta dorsalis as well as the vena caudalis can be clearly identified as bright spots beneath the spinal cord of the fish. The black area under the vessels represents part of the swim bladder.

Data analysis. $f_{\mathrm{H}}$ was derived from the pulsatile changes in ventral aortic blood pressure and counted for each temperature and cod. Values of $\mathrm{Pv}_{\mathrm{O}_{2}}$ recorded as percent air saturation were converted to $\mathrm{Pv}_{\mathrm{O}_{2}}$ (Torr; 1 Torr $=1 \mathrm{mmHg}=133.3 \mathrm{~Pa}$ ) using the following formula: $\mathrm{Pv}_{\mathrm{O}_{2}}=\left(\mathrm{P}_{\mathrm{atm}}-\mathrm{P}_{\mathrm{H} 2 \mathrm{O}}\right) \times 0.2095 \times(\%$ air saturation/100), where $\mathrm{P}_{\mathrm{atm}}$ is atmospheric pressure $(\mathrm{mmHg}), \mathrm{P}_{\mathrm{H} 2 \mathrm{O}}$ is water vapor pressure $(\mathrm{mmHg})$ dependent on temperature calculated after Dejours (9), and the fraction of oxygen in air is 0.2095 .

Mean signal intensities were calculated by an operator-controlled, pixel-by-pixel analysis of various regions of interest (ROIs) for the determination of relative blood flow changes. ROIs were obtained from the aorta dorsalis, the vena caudalis, and from muscle tissue. 


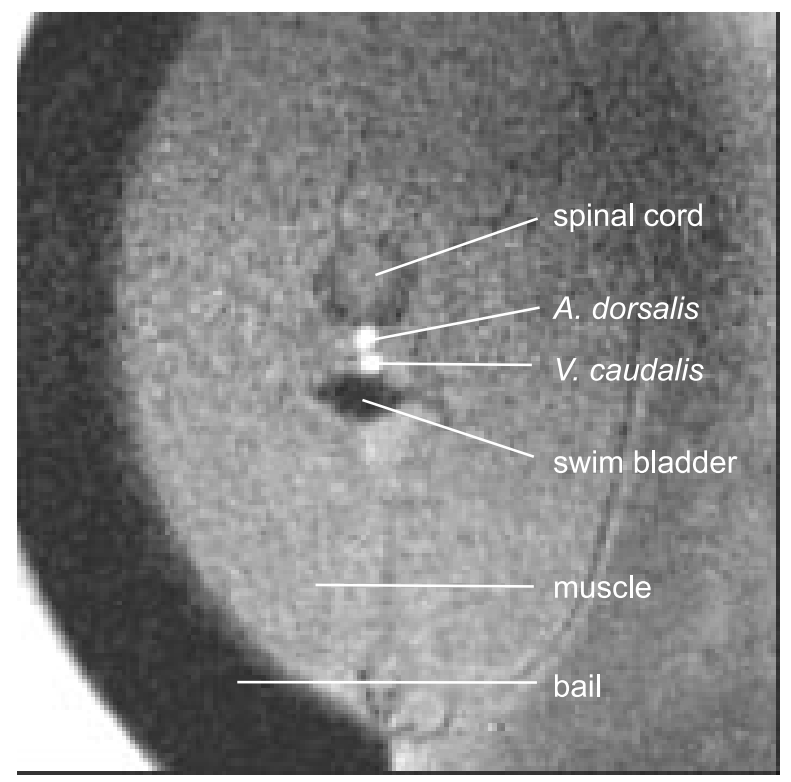

Fig. 1. Typical flow-weighted magnetic resonance image of an axial view of cod Gadus morhua obtained at the anterior end of the pectoral fin under control conditions $\left(10^{\circ} \mathrm{C}\right)$. A. dorsalis, aorta dorsalis; V. caudalis, vena caudalis. See text for explanations.

Ratios of vessel ROIs over those selected in muscle tissue were generated to correct for possible effects on image contrast other than by flow (e.g., longitudinal and transversal relaxation time, temperature). Blood flow changes are given in arbitrary units.

Statistics. Data are presented as means \pm SD for each temperature. Statistical significance was tested at the $P<0.05$ level using one-way ANOVA and post hoc Tukey tests (SigmaStat 2.0; SPSS). Discontinuities in slopes were calculated in Arrhenius plots after Yeager and Ultsch (42) followed by an $F$-test for slope comparisons. Regressions were calculated using SigmaPlot 8.0 (SPSS) and presented as means $\pm \mathrm{SE}$.

\section{RESULTS}

Acute temperature changes induced an immediate response of $f_{\mathrm{H}}$ of cod resulting in an exponential rise with increasing temperature (Fig. 2A). A typical on-line recording of $f_{\mathrm{H}}$ at various temperatures is shown in Fig. $3 ; f_{\mathrm{H}}$ decreased significantly during progressive cooling $\left(1^{\circ} \mathrm{C} / \mathrm{h}\right)$ from $36.6 \pm 3.6$ beats/min under control conditions $\left(10^{\circ} \mathrm{C}\right)$ to a minimum value of $17.5 \pm 3.2$ beats $/ \mathrm{min}$ at $2^{\circ} \mathrm{C}$. In response to warming $\left(1^{\circ} \mathrm{C} / \mathrm{h}\right), f_{\mathrm{H}}$ rose to a maximum of $65.9 \pm 4.1$ beats $/ \mathrm{min}$ at $19^{\circ} \mathrm{C}$. At temperatures below $7^{\circ} \mathrm{C}$ and above $12^{\circ} \mathrm{C}, f_{\mathrm{H}}$ was significantly different from control values at $10^{\circ} \mathrm{C}$. Over the total temperature range from 2 to $19^{\circ} \mathrm{C}$, best curve fit for temperature-dependent $f_{\mathrm{H}}$ yielded a polynomial quadratic regression. Arrhenius analysis revealed a discontinuity at $\sim 16^{\circ} \mathrm{C}$ (Fig. $2 B$ ). Accordingly, $f_{\mathrm{H}}$ displayed a clear exponential rise with temperature between 2 and $16^{\circ} \mathrm{C}$ following a mean $\mathrm{Q}_{10}$ of $2.38 \pm 0.35$. When cod started to show cardiac failure indicated by arrhythmia at high temperatures (see Fig. $3 B$ ), the water was cooled immediately; therefore, the number of data points in the high-temperature range is not sufficient for the comparison of regression slopes. Nonetheless, linear regression analysis of Arrhenius plots indicates a change in slope from -6.96 in the lower temperature range $\left(16.28^{\circ} \mathrm{C}\right.$ to $1.7^{\circ} \mathrm{C} ; P<$
$0.0001)$ to -2.50 in the high-temperature range $\left(18.8^{\circ} \mathrm{C}\right.$ to $16.6^{\circ} \mathrm{C} ; P=0.2123$ ) (Fig. $2 B$ ). One cod already failed to show an increase in $f_{\mathrm{H}}$ above $15^{\circ} \mathrm{C}$; these values were not included in the analysis and are shown as open squares in Fig. 2.

Mean values of arterial and venous blood flow derived from flow-weighted MRI data obtained in cod close to the anterior end of the pectoral fin are shown in Fig. 4. An overproportional drop in blood flow was observed when temperature fell below $4^{\circ} \mathrm{C}$, whereas no significant break point in flow was evident at temperatures beyond $4^{\circ} \mathrm{C}$ when blood flow increased moderately with temperature in both aorta dorsalis and vena caudalis. Best curve fit for both vessels yielded a hyperbolic regression reflecting a strong increase in blood flow in the lower and a moderate increase in the upper temperature range.

Changes in $\mathrm{Pv}_{\mathrm{O}_{2}}$ with temperature are shown in Fig. 5 for individual cod, since control values at $10^{\circ} \mathrm{C}$ differed between individuals and ranged from 18 to 70 Torr with a mean $\mathrm{Pv}_{\mathrm{O}_{2}}$ of

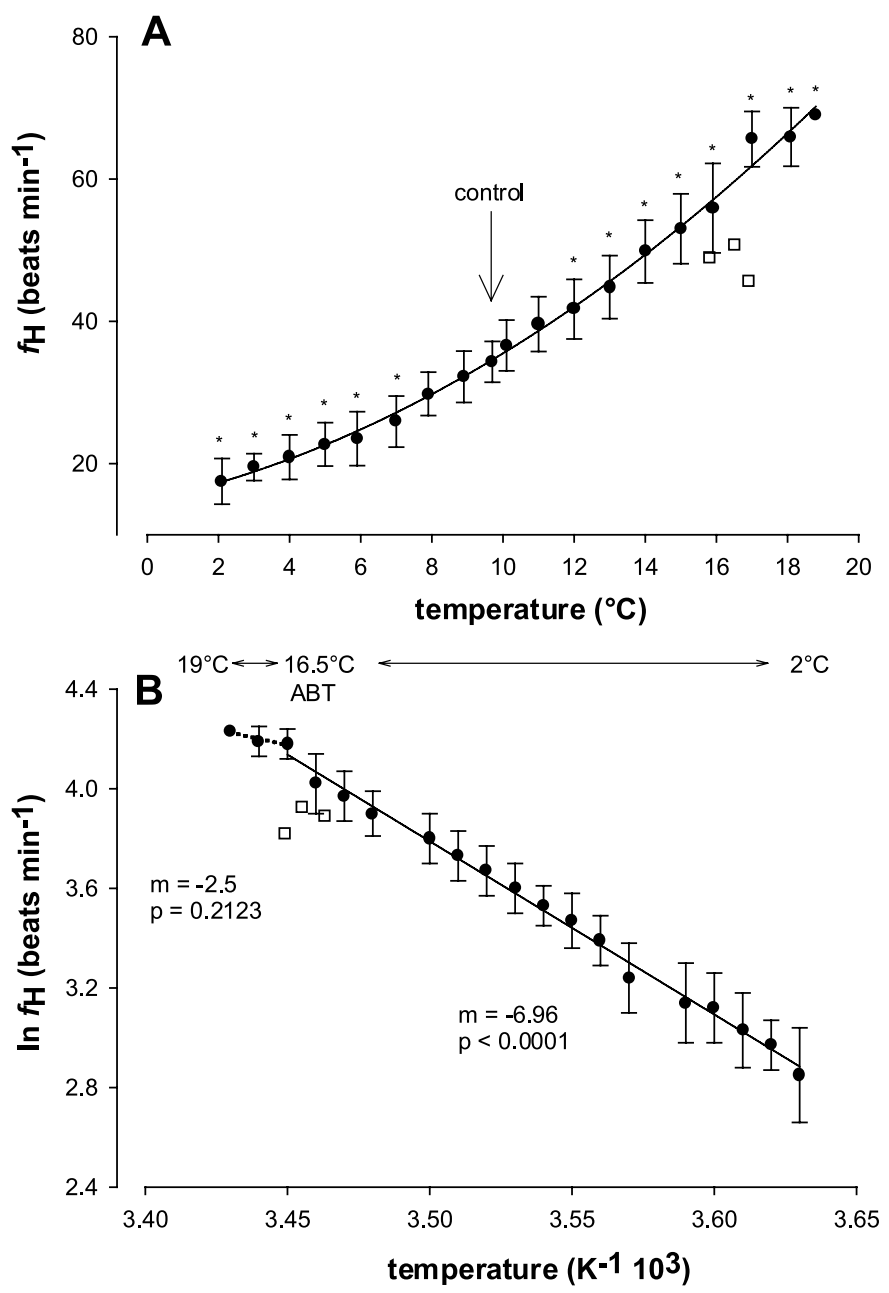

Fig. 2. Heart rate $\left(f_{\mathrm{H}}\right.$, beats $\left./ \mathrm{min}\right)$ of cod G. morhua during an acute temperature change $\left(1^{\circ} \mathrm{C} / \mathrm{h} ; n=3-4\right)$ depicted in a linear $(A)$ and in an Arrhenius plot $(B)$. $\square$, Data of 1 cod whose $f_{\mathrm{H}}$ failed to increase at $\sim 15^{\circ} \mathrm{C}$. $* f_{\mathrm{H}}$ values between 2 and $7^{\circ} \mathrm{C}$ and between 12 and $19^{\circ} \mathrm{C}$ were significantly different from control $f_{\mathrm{H}}$ at $10^{\circ} \mathrm{C}$. Best curve fit for temperature-dependent $f_{\mathrm{H}}$ yielded a polynomial quadratic regression $\left[f(x)=(15.2 \pm 1.5)+(0.9 \pm 0.3) \cdot x+(0.1 \pm 0.01) \cdot x^{2}\right.$; $\left.R^{2}=0.94 ; P<0.0001\right]$ with an Arrhenius break temperature (ABT) at $\sim 16.5^{\circ} \mathrm{C}$ and a decreased temperature dependence of $f_{\mathrm{H}}$ at temperatures beyond (dotted line-fit indicates an overall trend within the data). 


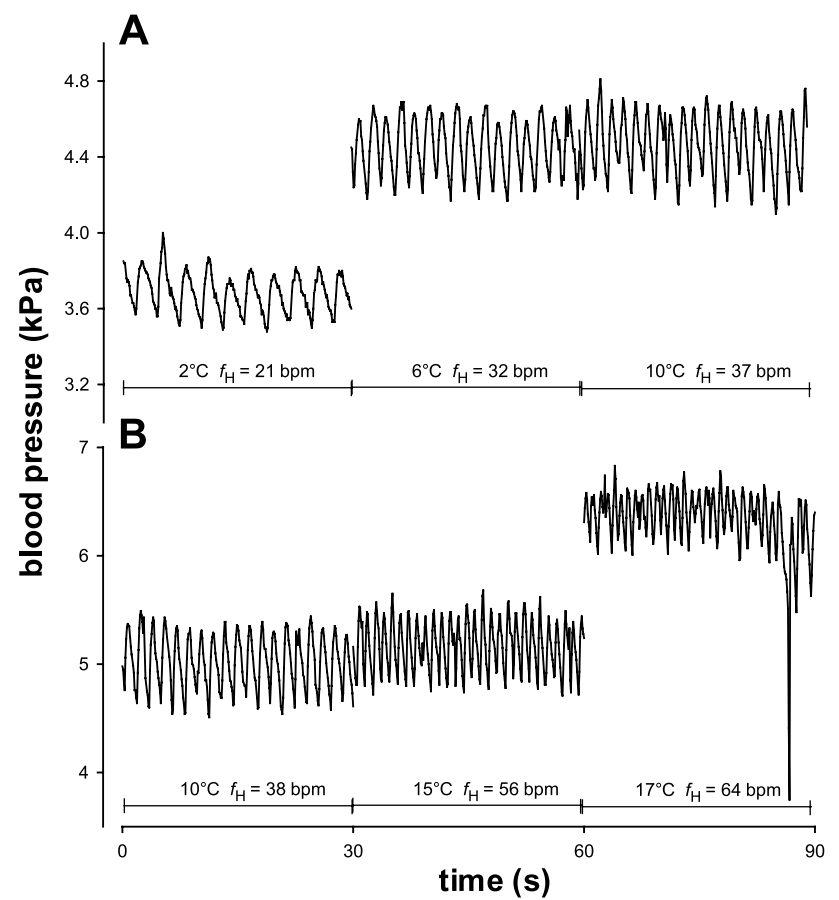

Fig. 3. Typical $f_{\mathrm{H}}$ recordings of an individual cod, G. morhua, at different temperatures. Note the onset of cardiac arrhythmia at $17^{\circ} \mathrm{C}$. bpm, Beats/min.

$41.7 \pm 17.8$ Torr $(35.8 \pm 11.8$ Torr, when data from one cod with unexpected high values were excluded). The high $\mathrm{Pv}_{\mathrm{O}_{2}}$ levels in this cod remain unexplained, but in response to cooling all cod showed an inverse U-shaped curve of temperature-dependent $\mathrm{Pv}_{\mathrm{O}_{2}}$ values with significant discontinuities in slopes at $4.7,5.1$, and $5.2^{\circ} \mathrm{C}$, respectively (Fig. $5 A$ ). As a general pattern, decreasing temperature from $10^{\circ} \mathrm{C}$ by $1^{\circ} \mathrm{C} / \mathrm{h}$ led to an increase in $\mathrm{Pv}_{\mathrm{O}_{2}}$ with maximum values at a mean temperature of $5.0 \pm 0.2^{\circ} \mathrm{C}$. Further cooling caused a progressive decrease in $\mathrm{Pv}_{\mathrm{O}_{2}}$.

When the temperature was increased from $10^{\circ} \mathrm{C}$ to $\sim 19^{\circ} \mathrm{C}$, all investigated cod showed a decrease in $\mathrm{Pv}_{\mathrm{O}_{2}}$ (Fig. 5B). An overproportional drop in $\mathrm{Pv}_{\mathrm{O}_{2}}$ became visible at temperatures $\sim 16^{\circ} \mathrm{C}$ with some variability between individual cod. Significant discontinuities in slopes were found at 16.4, 17, and $14.7^{\circ} \mathrm{C}$, respectively, resulting in a mean temperature at $16.0 \pm$ $1.2^{\circ} \mathrm{C}$. Above these temperatures the slope of the $\mathrm{Pv}_{\mathrm{O}_{2}}$ decrement was significantly increased (see legend of Fig. 5 for regression analysis).

Figure 6 summarizes the observed changes in $\mathrm{Pv}_{\mathrm{O}_{2}}$, using values normalized to percentage of controls. Temperaturedependent measurements of $\mathrm{Pv}_{\mathrm{O}_{2}}$ revealed the highest values at $5.0 \pm 0.2^{\circ} \mathrm{C}$. Figure 6 contains assigned tolerance ranges and threshold temperatures using the definition and terminology used by Frederich and Pörtner (Ref. 16; see DISCUSSION). The optimum temperature range $\left(\mathrm{T}_{\mathrm{o}}\right)$ was interpreted as being limited by pejus values at temperatures $\left(\mathrm{T}_{\mathrm{p}}\right)$ when $\mathrm{Pv}_{\mathrm{O}_{2}}$ values fell significantly below maximum values at $5^{\circ} \mathrm{C}$. The lower $\mathrm{T}_{\mathrm{p}}$ (I) was set to $1.6^{\circ} \mathrm{C}$ and the upper $\mathrm{T}_{\mathrm{p}}$ (II) to $7.3^{\circ} \mathrm{C}$, respectively. A $\mathrm{T}_{\mathrm{c}}$ is indicated at $16.0 \pm 1.2^{\circ} \mathrm{C}$ when $\mathrm{Pv}_{\mathrm{O}_{2}}$ dropped more strongly during warming (only seen in Fig. $5 B$ in each individual pattern of $\mathrm{Pv}_{\mathrm{O}_{2}}$ development), in line with the onset of cardiac arrhythmia.

\section{DISCUSSION}

Methodology. The aim of this study was to quantify the thermal tolerance window of G. morhua from the North Sea by investigating the relationships between thermal tolerance and oxygen delivery through the determination of temperaturedependent $f_{\mathrm{H}}$, arterial and venous blood flow, and $\mathrm{Pv}_{\mathrm{O}_{2}}$ in the ductus Cuvier.

The use of the last gill arch for recording $f_{\mathrm{H}}$ via the afferent branchial artery made catheter fixation easier than via use of the second or third gill arches. Strong ventilation especially at high temperatures did not affect the implant and thus the quality of recordings. Because electronic equipment is affected by strong magnetic fields, it was necessary to use a long catheter $(\sim 2 \mathrm{~m})$ between the center of the MRI system (location of the fish chamber) and the pressure transducer. Nevertheless, the reliability of the approach was supported by the quality of the recordings (Fig. 3).

In a recent study MRI could not be performed in unanesthetized pelagic fish because fish movements led to image artefacts with classical MRI techniques (5). Minimizing the range of movements by bails as well as the use of a faster MRI technique (Snapshot FLASH, Ref. 18) solved this problem and revealed flow-weighted magnetic resonance images in similarly good quality as obtained in immobilized crustacea (4) and in benthic (inactive) marine fish $(5,23)$. It can be assumed that each individual fish was undisturbed and in steady state with minimal influence by handling stress. The cod showed no fight-or-flight response after recovery from anesthesia. The measurement of blood flow by using flow-weighted MRI rather than traditional flow probes provided the main advantage of yielding arterial and venous blood flow simultaneously (see Ref. 4). The degree to which blood flow is underestimated by data averaging over time is considered minimal, because the development of temperature-dependent blood flow mirrors the pattern of venous oxygen levels and the effects of a higher

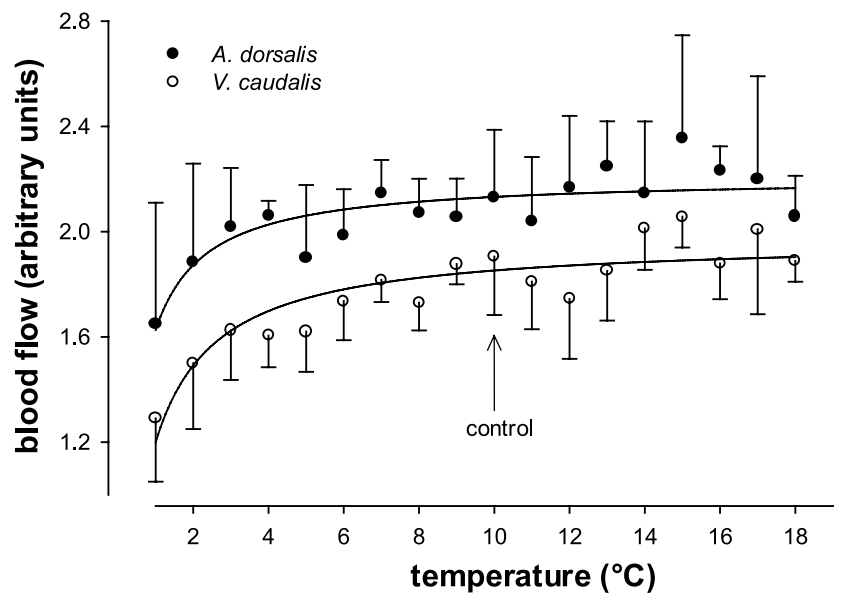

Fig. 4. Relative blood flow changes in the aorta dorsalis and vena caudalis of cod G. morhua with acute temperature changes by $1^{\circ} \mathrm{C} / \mathrm{h}$ starting at control temperature $10^{\circ} \mathrm{C}(n=3)$. Best curve fit for both vessels yields a hyperbolic regression with a strong increase in blood flow in the lower and a moderate increase in the upper temperature range. Aorta dorsalis: $f(x)=(2.3 \pm$ $0.05) \cdot x /[(0.7 \pm 0.2)+x] ; R^{2}=0.21 ; P<0.0001$. Vena caudalis: $f(x)=$ $(2.1 \pm 0.04) \cdot x /[(1.2 \pm 0.2)+x] ; R^{2}=0.45 ; P<0.0001$. 
Fig. 5. Venous $\mathrm{PO}_{2}\left(\mathrm{PvO}_{2}\right)$ measured in the ductus Cuvier of $\operatorname{cod} G$. morhua with acute temperature decrements $(A)$ and increments $(B)$ starting at a control temperature of $10^{\circ} \mathrm{C}$. Graphs represent recordings in individual cod. Arrows indicate the temperature at which significant discontinuities in slopes of $\mathrm{Pv}_{\mathrm{O}_{2}}$ occurred during temperature changes. A temperature decrease led to inverse U-shaped curves with maximum values of $\mathrm{Pv}_{\mathrm{O}_{2}}$ at $\sim 5^{\circ} \mathrm{C}$. I: $f(x)=(39.5 \pm 1.2)+$ $(5.8 \pm 0.4) \cdot x-(0.6 \pm 0.03) \cdot x^{2} ; R^{2}=0.56 ; P<$ 0.0001. II: $f(x)=(32.04 \pm 0.7)+(4.3 \pm 0.3) \cdot x-$ $(0.6 \pm 0.03) \cdot x^{2} ; R^{2}=0.77 ; P<0.0001$. III: $f(x)=$ $(52.02 \pm 2.1)+(18.5 \pm 0.8) \cdot x-(1.7 \pm 0.07) \cdot x^{2}$; $R^{2}=0.59 ; P<0.0001$. A temperature increase led to progressively decreasing values of $\mathrm{Pv}_{\mathrm{O}_{2}}$, turning into a significantly larger slope at temperatures of $\sim 16^{\circ} \mathrm{C}$. I: $f\left(10-16.4^{\circ} \mathrm{C}\right)=(80.1 \pm 1.2)-(3.8 \pm 0.09) \cdot x$; $R^{2}=0.83 ; P<0.0001 ; f\left(16.6-17.3^{\circ} \mathrm{C}\right)=(195.3 \pm$ $31.7)-(10.6 \pm 1.9) \cdot x ; R^{2}=0.45 ; P<0.0001$. II: $f\left(10-16.9^{\circ} \mathrm{C}\right)=(45.8 \pm 0.8)-(0.09 \pm 0.06) \cdot x$; $R^{2}=0.006 ; P=0.1145 ; f\left(17-19.6^{\circ} \mathrm{C}\right)=(159.8 \pm$ $6.9)-(6.8 \pm 0.4) \cdot x ; R^{2}=0.64 ; P<0.0001$. III: $f\left(10-14.6^{\circ} \mathrm{C}\right)=(47.9 \pm 0.7)-(1.7 \pm 0.06) \cdot x ; R^{2}=$ $0.73 ; P<0.0001 ; f\left(14.7-19.2^{\circ} \mathrm{C}\right)=(58.5 \pm 1.01)-$ $(2.4 \pm 0.06) \cdot x ; R^{2}=0.87 ; P<0.0001$.
A
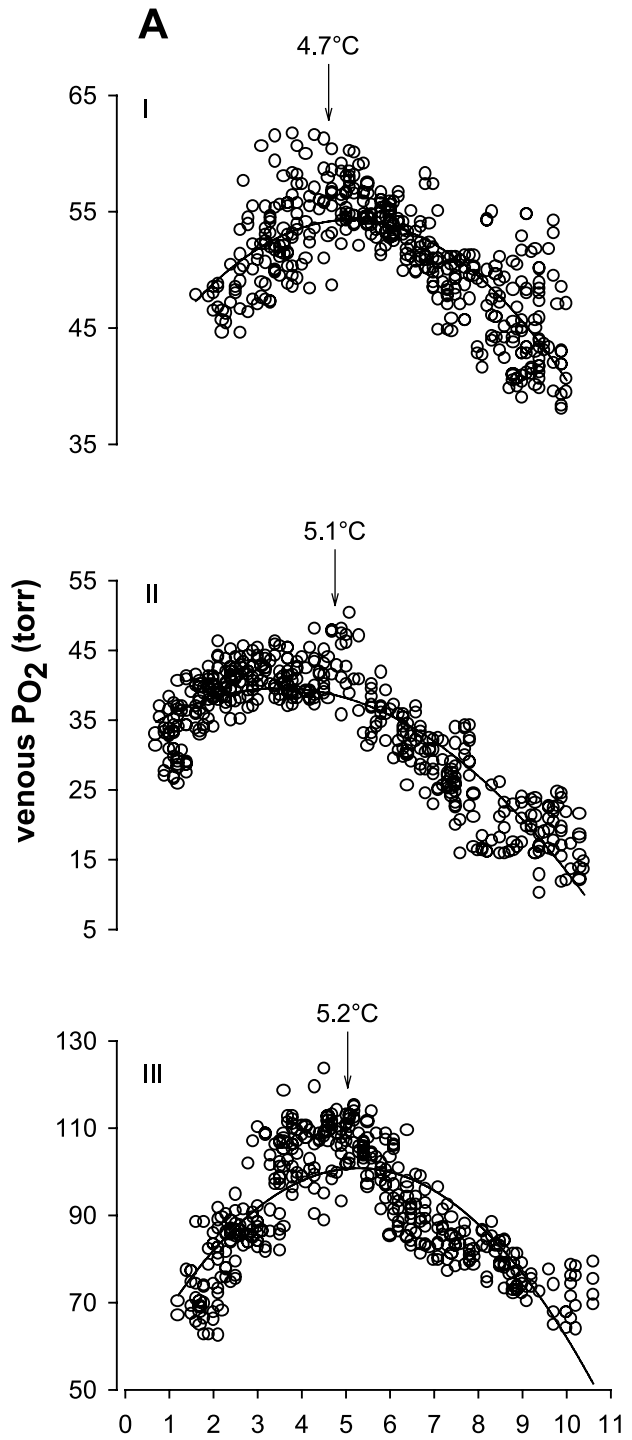

B
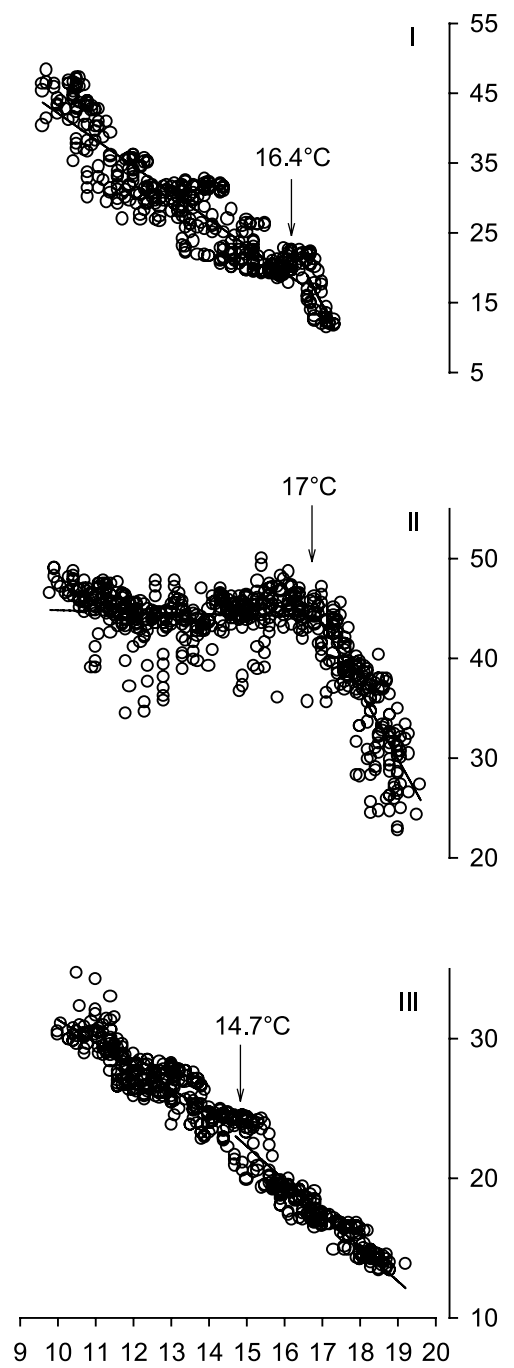

temperature $\left({ }^{\circ} \mathrm{C}\right)$

oxygen consumption rate on venous oxygen levels at higher temperatures.

Low $\mathrm{Pv}_{\mathrm{O}_{2}}$ values recorded after surgery increased to constantly high values during recovery, a pattern similar to the one recently described by Farrell and Clutterham (13). The slope of the $\mathrm{Pv}_{\mathrm{O}_{2}}$ change during recovery is a good indicator of a favorable position of the optode in the ductus Cuvier. Overall, our findings support the suitability of the optode system as a tool for $\mathrm{PvO}_{2}$ measurements in the circulatory and ventilatory system of aquatic animals $(13,16,37)$. Using classical blood measuring systems, Davie and Farrell (8) reported $\mathrm{Pv}_{\mathrm{O}_{2}}$ in resting fish near 30-40 Torr, which corresponds to the mean value resulting from our data. Moreover, $\mathrm{Pv}_{\mathrm{O}_{2}}$ were very variable, but changes with temperature followed similar slopes despite different starting values.

The rather rapid and progressive temperature change used in this study does not represent a situation that cod would likely experience in its natural environment. However, the experimental protocol was chosen such that cod had no time to acclimate to different temperatures; therefore, an influence of acclimation phenomena that may involve adaptive shifts in thresholds of thermal tolerance can likely be excluded.

Cardiovascular performance. Mean control $f_{\mathrm{H}}$ was $36.6 \pm$ 3.6 beats $/ \mathrm{min}$ at $10^{\circ} \mathrm{C}$ and is in good agreement with those reported for Atlantic cod by Pettersson and Nilsson (27), Axelsson and Nilsson (1), and Webber et al. (41). Heart rates obtained at 2,5 , and $7^{\circ} \mathrm{C}$ of $17.5 \pm 3.2,22.7 \pm 3.0$, and $25.9 \pm$ 3.6 beats/min, respectively, are similar to the 18 beats $/ \mathrm{min}$ $\left(2.5^{\circ} \mathrm{C}\right), 22$ beats $/ \mathrm{min}\left(5^{\circ} \mathrm{C}\right)$, and 27 beats $/ \mathrm{min}\left(7.5^{\circ} \mathrm{C}\right)$ obtained in $5^{\circ} \mathrm{C}$-acclimated Nova Scotia cod swimming at a low speed of $7 \mathrm{~cm} / \mathrm{s}(7)$. Heartbeat frequency of cod responded quickly to changes in water temperature and displayed a more or less exponential change (Fig. 2). The $\mathrm{Q}_{10}\left(2-16^{\circ} \mathrm{C}\right)$ of $2.38 \pm 0.35$ fits well with the range of values between 1.3 and 3 found for routine $f_{\mathrm{HS}}$ in other species (see Refs 10,11 ).

However, cod could not enhance $f_{\mathrm{H}}$ much beyond $16^{\circ} \mathrm{C}$, and cardiac arrhythmia became visible (see Figs. $2 B$ and 3 ), indicating dysfunction in cardiovascular performance at higher temperatures. Farrell (11) assumed a temperature-induced upper frequency limit for $f_{\mathrm{H}}$ of $\sim 120$ beats/min for most fish 


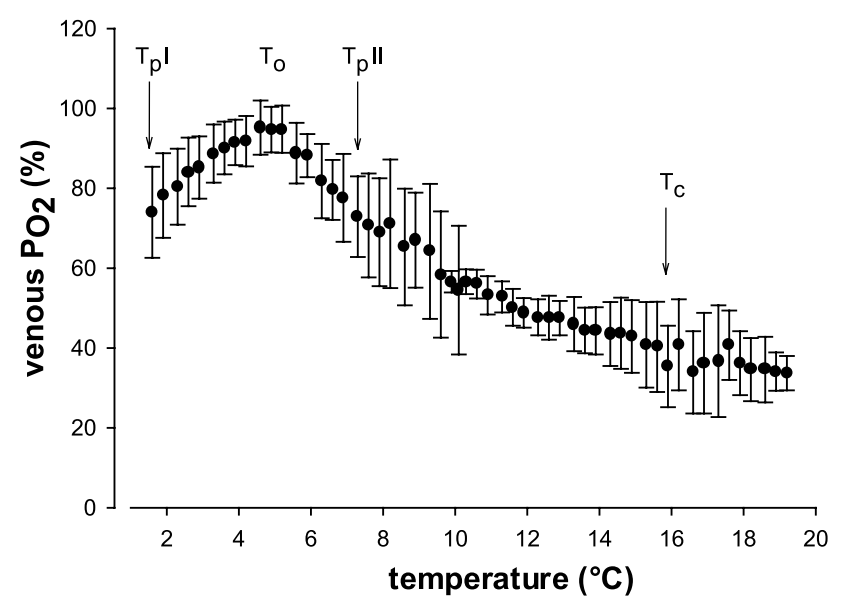

Fig. 6. Summarized relative $(\%)$ changes in $\mathrm{Pv}_{2}$ measured in the ductus Cuvier of $\operatorname{cod} G$. morhua during acute temperature changes starting from the control temperature of $10^{\circ} \mathrm{C}$. Data are expressed as percent fractions of the highest $\mathrm{PVO}_{2}$ values $(n=3$, different animals for temperature decrease and increase). Arrows indicate the optimum temperature range $\left(\mathrm{T}_{\mathrm{o}}\right)$ with highest $\mathrm{Pv}_{\mathrm{O}_{2}}$ values bordered by pejus temperatures $\left(\mathrm{T}_{\mathrm{p}} \mathrm{I}\right.$ and $\mathrm{T}_{\mathrm{p}}$ II identify the temperatures at which $\mathrm{Pv}_{\mathrm{O}_{2}}$ values fell significantly below the maximum) and the upper critical temperatures $\left(\mathrm{T}_{\mathrm{c}}\right)$ which identify onset of a significantly stronger decrease in $\mathrm{PV}_{2}$ during warming. The discontinuity in slope at the upper $\mathrm{T}_{\mathrm{c}}$ is better seen in the data from individual cod (see Fig. $5 B$ ). The mean values revealed no obvious drop in $\mathrm{Pv}_{\mathrm{O}_{2}}$ at $\sim 16^{\circ} \mathrm{C}$ due to the variability in temperature-dependent patterns of $\mathrm{Pv}_{2}$ seen in individual cod.

species, depending, however, on acclimation temperature. Temperature affects pacemaker discharge by decreasing the action potential duration during warming (19). Furthermore, warm (cold) acclimation increases (decreases) the temperature limit beyond which $f_{\mathrm{H}}$ as well as pacemaker rate drop. During acute temperature increase $\left(1.5^{\circ} \mathrm{C} / \mathrm{h}\right), f_{\mathrm{H}}$ of $15^{\circ} \mathrm{C}$-acclimated rainbow trout, $S$. gairdneri, reached a maximum of $\sim 110$ beats/min between 22 and $24^{\circ} \mathrm{C}$ (20). Cold acclimation of goldfish, Carassius auratus, led to a drop in maximum $f_{\mathrm{H}}$ of isolated hearts. A maximum of 38 beats $/ \mathrm{min}$ at $16.3^{\circ} \mathrm{C}$ in hearts from lower acclimation temperatures $\left(10^{\circ} \mathrm{C}\right)$ compares to a maximum of 51 beats $/ \mathrm{min}$ at $24^{\circ} \mathrm{C}$ in isolated hearts of warm $\left(25^{\circ} \mathrm{C}\right)$-acclimated animals $(39)$. With further warming, $f_{\mathrm{H}}$ decreased, became irregular, and stopped.

In our experiments with cod acclimated to $10^{\circ} \mathrm{C}$, the maximum of $f_{\mathrm{H}}$ in vivo seemed to be reached at $65.6 \pm 3.89$ beats/min for temperatures $>16^{\circ} \mathrm{C}$. This finding is in line with observations by Rinne et al. (35), who reported that temperature-dependent $f_{\mathrm{H}}$ of Norwegian cod G. morhua never exceeded 70 beats/min. To minimize thermal stress, we did not increase temperature above $\sim 19^{\circ} \mathrm{C}$ and immediately reduced temperature when cardiac arrhythmia became visible. Therefore, a potential decrease in $f_{\mathrm{H}}$ at even higher temperatures likely occurs outside the range of experimental temperatures of the present study. Only one cod displayed a decrease in $f_{\mathrm{H}}$ beyond $16^{\circ} \mathrm{C}$ (see open squares in Fig. 2), emphasizing that a high tolerance limit is reached in $\operatorname{cod}$ at $\geq 16^{\circ} \mathrm{C}$ with some variability between individuals. The observed variability between individual cod might be due to variable levels of temperature stress according to aerobic fitness and the potential use of the stress response. In most fish, epinephrine is the predominant catecholamine affecting contractility of the heart (14), and it was shown that the level of epinephrine increases under conditions of stress $(24,25)$. Such variable adrenergic stimu- lation of the fish heart might have contributed to the observed variability in thermal limits.

According to our present results, an upper limit to pacemaker discharge and $f_{\mathrm{H}}$ in vivo may also be set by the level of oxygen supply that decreases upon warming (see Figs. 5 and 6 and discussion below). This hypothesis is in line with observations reported by Sartoris et al. (37) who defined a $\mathrm{T}_{\mathrm{c}}$ close to $16^{\circ} \mathrm{C}$ when North Sea cod showed a sudden drop in intracellular $\mathrm{pH}$ and energetic collapse in white muscle. At the $\mathrm{T}_{\mathrm{c}}$, aerobic scope becomes nil and anaerobic metabolism sets in (cf. Ref. 30). In our previous study, the fish died within $1 \mathrm{~h}$ despite immediate cooling. In our present study, cooling on the onset of cardiac arrhythmia rescued the fish, which indicates that onset of dysfunction in cardiac performance is an early marker for the upper $\mathrm{T}_{\mathrm{c}}$ in fish.

The hyperbolic pattern in blood flow of aorta dorsalis and vena caudalis with increasing temperature (Fig. 4) indicates that a temperature-induced increase in $f_{\mathrm{H}}$ is not reflected by a similar factorial increment in relative blood flow. This is in line with Farrell's suggestion that cardiac contractility, which is an important determinant of arterial blood pressure in vivo, and stroke volume decrease with rising temperature $(11,12)$. In line with our findings, Heath and Hughes (20) found only a slight increase in blood pressure with temperature in rainbow trout, $S$. gairdneri. Similarly, no temperature-dependent change in blood pressure was observed in turtle, Trachemys scripta (17). These patterns might explain the mismatch between elevated $f_{\mathrm{H}}$ and blood flow at higher temperatures. Enhanced arterial and venous vasodilatation at higher temperatures could also explain the limited increment in blood flow (measured as relative distance per unit time) such that a somewhat stronger increase in volume flow is conceivable. Vessel diameters were around 1.5-2.0 $\mathrm{mm}$, depending on fish size and the position of the imaging slice relative to the fish; therefore, an in-plane resolution of $470 \mu \mathrm{m} /$ pixel will not resolve volume changes $<20 \%$. However, changes in the diameter of blood vessels were not visible in the MR images, and therefore volume changes were most likely $<20 \%$ if they occurred.

The measurements of $\mathrm{Pv}_{\mathrm{O}_{2}}$ in the ductus Cuvier at different temperatures support the conclusion that a mismatch between organismic oxygen demand and oxygen supply by the cardiovascular system sets in during both warming and cooling (Fig. 5). Highest $\mathrm{Pv}_{\mathrm{O}_{2}}$ values in cod were obtained at $5.0 \pm 0.2^{\circ} \mathrm{C}$, indicating an optimum temperature for energy-efficient blood oxygen transport in cod. Below $2^{\circ} \mathrm{C}$ and above $7^{\circ} \mathrm{C}, \mathrm{Pv}_{\mathrm{O}_{2}}$ fell significantly below maximum $\mathrm{Pv}_{\mathrm{O}_{2}}$. A rising difference between arterial $\mathrm{PO}_{2}$ and $\mathrm{Pv}_{\mathrm{O}_{2}}$ during warming was also observed by Heath and Hughes (20) in rainbow trout and by Sartoris et al. (37) in cod. Below $5^{\circ} \mathrm{C}$, the lower $\mathrm{Pv}_{\mathrm{O}_{2}}$ values likely resulted from a larger effect of cooling on circulatory oxygen supply than on oxygen demand. This conclusion is supported by the strong decrease in blood flow observed below $5^{\circ} \mathrm{C}$. The reduction in flow caused the decrease in $\mathrm{Pv}_{\mathrm{O}_{2}}$, which became significant below $2^{\circ} \mathrm{C}$, defining the lower $\mathrm{T}_{\mathrm{p}}$.

Above $5^{\circ} \mathrm{C}$ the decrease in $\mathrm{Pv}_{\mathrm{O}_{2}}$ may indicate that increased tissue oxygen consumption was not fully compensated for by increased oxygen supply through blood flow, leading to the upper $\mathrm{T}_{\mathrm{p}}$ temperature above which $\mathrm{Pv}_{\mathrm{O}_{2}}$ is significantly reduced, and finally the upper $\mathrm{T}_{\mathrm{c}}$ was reached where arrhythmia set in and contributed to the overproportional drop in $\mathrm{Pv}_{\mathrm{O}_{2}}$. $\mathrm{PV}_{\mathrm{O}_{2}}$ mirrors the level of oxygen remaining in the blood after 
oxygen diffusion to tissues is finalized. In the case of fish hearts without coronary circulation, this $\mathrm{PO}_{2}$ is in fact the "arterial" pressure head of oxygen diffusion to the cardiac tissue. Therefore, the statement that the pattern of $\mathrm{Pv}_{\mathrm{O}_{2}}$ change is an indicator of a progressive mismatch between circulatory oxygen supply and elevated metabolic rate is valid for the heart of the fish itself.

All of these observations indicate a limitation in blood flow and associated oxygen transport as a mechanism contributing to oxygen-limited thermal tolerance in fish. A similar pattern was found in Antarctic eelpout, Pachycara brachycephalum, by Mark et al. (23) when temperature was increased by $1{ }^{\circ} \mathrm{C}$ once every $12 \mathrm{~h}$. They reported blood flow in the aorta dorsalis to rise steadily up to $6^{\circ} \mathrm{C}$, when no further increase occurred. It was suggested that a $T_{p}$ was reached close to $7^{\circ} \mathrm{C}$ in the Antarctic eelpout when blood flow became limiting likely due to insufficient cardiovascular performance. A limiting role of blood flow in thermal tolerance is emphasized by observations of Blank et al. (3) who demonstrated that the function of isolated tuna hearts could be retained at $30^{\circ} \mathrm{C}$ only if input pressure was elevated to produce maximal flow conditions before warming, whereas arrhythmia or failure of the heart occurred under standard conditions of ambient input pressure.

$\mathrm{Pv}_{\mathrm{O}_{2}}$ optima may shift on thermal acclimation. Webber et al. (41) reported a smaller difference between arterial and venous oxygen contents in cod collected on the Scotian shelf and acclimated at $5^{\circ} \mathrm{C}$ compared with animals acclimated to $10^{\circ} \mathrm{C}$. This pattern was explained by the observed lower $\mathrm{Q}_{10}$ value for cardiac output than for oxygen consumption. As cod from the North Sea are genetically distinct from the Scotian shelf cod used by Pogson et al. (28) and Webber et al. (41), further investigations within and comparisons between populations appear warranted.

In the first study that elaborated the relationships between temperature-dependent critical and pejus thresholds in an animal organism, $\mathrm{T}_{\mathrm{p}} \mathrm{s}$ were identified on both sides of a wide plateau of high arterial $\mathrm{PO}_{2}$ in the spider crab Maja squinado (16). The respective threshold values were in fact those found to delineate the geographical distribution range of these animals. Such a clear analysis may not yet be possible for cod. Arterial $\mathrm{PO}_{2}$ does not display a temperature-limited plateau in cod, likely due to the nonlimited capacity of ventilation within the thermal tolerance range (cf. Ref. 37). Our present observations in venous blood indicate a lower $\mathrm{T}_{\mathrm{p}}$ at $1.6^{\circ} \mathrm{C}\left(\mathrm{T}_{\mathrm{p}} \mathrm{I}\right)$ and an upper $\mathrm{T}_{\mathrm{p}}\left(\mathrm{T}_{\mathrm{p}} \mathrm{II}\right)$ at $7.3^{\circ} \mathrm{C}$. This would be lower than our previous estimate (37) of an upper $\mathrm{T}_{\mathrm{p}}$ close to $16^{\circ} \mathrm{C}$, just below the $\mathrm{T}_{\mathrm{c}}$. Considering the pattern of whole organism oxygen demand (15), the development of venous $\mathrm{PO}_{2}$ and blood flow in North Sea cod indicates, however, that the decrement in aerobic scope starts early on beyond $7^{\circ} \mathrm{C}$ but may be much shallower in North Sea cod than seen in Antarctic eelpout by Mark et al. (23) such that the range of thermal tolerance may be widened and the pejus range may not become limiting until closer to $16^{\circ} \mathrm{C}$ (37). Thus the loss in aerobic scope in the pejus range may occur more slowly in eurythermal cod with moderate effects on functional scope and flexibility.

A sharp drop in $\mathrm{Pv}_{\mathrm{O}}$, was only reached at $\sim 16^{\circ} \mathrm{C}$, with some variability between individual cod as shown in Fig. 5. This may be a fatal drop as expected at the $T_{c}$ when energetic deficiency sets in (37). The mean value of $\mathrm{T}_{\mathrm{c}}$ at $16.0 \pm 1.2^{\circ} \mathrm{C}$ found here is in good agreement with previous data by Sartoris et al. (37).
The $T_{c}$ might reflect onset of insufficient oxygen supply to the heart as oxygen tension in the ductus Cuvier decreased to $25.4 \pm 8.9$ Torr. This low pressure head may elicit the observed dysfunction in heart performance at higher temperatures. This threshold value is higher than the limit of 8-10 Torr suggested by Steffensen and Farrell (38) and Sartoris et al. (37) and might be explained by the location of the optode in the ductus Cuvier, which lacks venous blood from the sinus venosus of the liver.

Sartoris et al. (37) found arterial $\mathrm{Po}_{2}$ largely constant during warming, and thus arterial oxygen uptake (i.e., ventilation) did not become limiting in cod within the range of thermal tolerance. Our present findings indicate that circulatory rather than ventilatory performance sets the limit of thermal tolerance in cod in line with conclusions by Mark et al. (23) for Antarctic eelpout. This contrasts the situation in crustaceans (16) where breakpoints in ventilation, $f_{\mathrm{H}}$, and arterial hemolymph $\mathrm{Po}_{2}$ coincided in the spider crab $M$. squinado. In cod, myocardial oxygen supply is provided by venous blood. A warminginduced right shift in $\mathrm{O}_{2}$-hemoglobin dissociation curve would favor oxygen supply to the myocardium (13); however, less oxygen may remain for the myocardium due to rising oxygen uptake by other tissues. The conclusion emerging from the present data that the upper lethal temperature in cod is set by dysfunction in cardiocirculation due to insufficient oxygen supply matches the respective conclusions for exercising fish by Farrell (12). Maximal exercise in fish acclimated at temperatures above the thermal optimum led to a decrease in $\mathrm{Pv}_{\mathrm{O}_{2}}$ below the venous oxygen threshold required to support maximum cardiac performance. Therefore, the heart became hypoxic and lost scope when temperature approached the upper limit (12). These considerations are in line with the progressive temperature-dependent loss in whole organism aerobic scope suggested by the present study.

Ecological implications. The present findings indicate that oxygen supply to tissues is optimal with probably lowest energetic costs in a relatively narrow temperature range of $\sim 5^{\circ} \mathrm{C}$ in North Sea cod acclimated to $10^{\circ} \mathrm{C}$.

In situ observations of the natural thermal range of cod and its thermal preference and limitation match the present finding of an optimum and likely most energy-efficient pattern of oxygen supply between 2 and $7^{\circ} \mathrm{C}$ for North Sea cod. North Sea surface temperatures vary between monthly averages of 7 to $16^{\circ} \mathrm{C}(22)$. During May to June, a seasonal thermocline can develop that deepens throughout the summer and breaks down by November. Bottom water temperatures remain between 6 and $8^{\circ} \mathrm{C}$ throughout summer (6). In the light of the present data, higher summer temperatures of surface waters are a likely reason for cod to spend much or most of their time on the sea floor and to revert to vertical migrations only during October and November. Furthermore, no cod are found in the southern North Sea during warm summers despite sufficient abundance of prey (R. Knust, unpublished observations). Although significant aerobic scope is still present at the acclimation temperature of $10^{\circ} \mathrm{C}$, this temperature is already beyond the thermal optimum of adult North Sea cod. This might be the reason why cod avoid higher temperatures in their natural environment when their limited aerobic scope hampers the expression of full performance during active hunting for prey.

Within the pejus range, survival is supported by full availability of aerobic scope. Aerobic performance, which is also 
essential for growth and reproduction, becomes progressively restricted at temperatures beyond the upper $T_{p}$ (33). The shallow decrease in aerobic performance seen in cod is emphasized by the observation that optimal growth under ad libitum feeding in laboratory studies was observed at $\sim 10^{\circ} \mathrm{C}$ $(15,31)$. In the field where higher levels of aerobic exercise are required for collecting food, a limitation of population performance of cod may set in somewhat earlier, beyond $7^{\circ} \mathrm{C}$. The progressive performance decrement during warming would continue slowly until close to the observed $\mathrm{T}_{\mathrm{c}}$ at $16.0 \pm 1.2^{\circ} \mathrm{C}$ when the drop in $\mathrm{Pv}_{\mathrm{O}}$, becomes fatal. Such fatal limitation may then explain the high $88 \%$ mortality in Iceland cod when acclimated to $15.6^{\circ} \mathrm{C}(2)$ and the higher mortality for North Sea cod acclimated to $15^{\circ} \mathrm{C}$ compared with lower acclimation temperatures (15).

\section{Perspectives}

During acute temperature change, oxygen supply through cardiovascular performance of resting 1-kg cod North Sea cod, G. mоrhua, acclimated to $10^{\circ} \mathrm{C}$ appears optimal at temperatures $\sim 5^{\circ} \mathrm{C}$, indicated by maximum values of $\mathrm{Pv}_{\mathrm{O}_{2}}$ and moderate $f_{\mathrm{H}} \mathrm{s}$. Below and above $5^{\circ} \mathrm{C}, \mathrm{Pv}_{\mathrm{O}_{2}}$ decreased, indicating onset of a progressive mismatch between oxygen delivery and demand due to insufficient upregulation of blood flow. Thermal limitation may, therefore, already set in at the transition from optimum to pejus range starting at temperatures below $2^{\circ} \mathrm{C}$ and beyond $7^{\circ} \mathrm{C}$. At temperatures above $16^{\circ} \mathrm{C}$, an enhanced drop in $\mathrm{Pv}_{\mathrm{O}_{2}}$ was observed paralleled by the onset of cardiac arrhythmia toward higher temperatures, indicating the loss of aerobic scope at the $T_{c}$. These findings reveal a wide shallow pejus range between 7 and $16^{\circ} \mathrm{C}$. The finding of a relatively early onset of reduced performance is in good agreement with the general knowledge of thermal preference and distribution of cod $(21,26,36)$. These considerations support a recent hypothesis of why global warming causes a northward shift of the geographical distribution of G. morhua from the North Sea (31). Future analysis will have to address the genetic, molecular, and cellular basis for cardiovascular performance and its thermal optimization. Further study is also required to quantify the consequences of a thermal optimum of oxygen supply for the various processes of organismic and population performance depending on whole animal aerobic scope in the field.

\section{ACKNOWLEDGMENTS}

We thank R. M. Wittig for technical support as well as F. Melzner for assistance during some of the surgeries.

We declare that experiments performed during this study comply with current legislation.

\section{GRANTS}

This study is a contribution to the ELOISE project "Effects of climate induced temperature change on marine coastal fishes (CLICOFI)," funded by the European Union program "Climate and Environment," contract no. ENV4CT97-0596.

\section{REFERENCES}

1. Axelsson $\mathbf{M}$ and Nilsson S. Blood pressure control during exercise in the Atlantic cod, Gadus morhua. J Exp Biol 126: 225-236, 1986.

2. Björnsson B, Steinarsson A, and Oddgeirsson M. Optimal temperature for growth and feed conversion of immature cod (Gadus morhua L.). ICES J Mar Science 58: 29-38, 2001.
3. Blank JM, Morrissette JM, Landeira-Fernandez AM, Blackwell SB, Williams TD, and Block BA. In situ cardiac performance of Pacific bluefin tuna hearts in response to acute temperature change. $J$ Exp Biol 207: 881-890.

4. Bock C, Frederich M, Wittig RM, and Pörtner HO. Simultaneous observations of haemolymph flow and ventilation in marine spider crabs at different temperatures: a flow weighted MRI study. Magn Reson Imaging 19: 1113-1124, 2001.

5. Bock C, Sartoris FJ, and Pörtner HO. In vivo MR spectroscopy and MR imaging on non-anaesthetized marine fish: techniques and first results. Magn Reson Imaging 20: 165-172, 2002.

6. Brander K. Spawning and Life History Information for North Atlantic Cod Stocks (ICES Cooperative Research Report No. 205): Copenhagen: International Council for the Exploration of the Sea, 1994.

7. Claireaux G, Webber DM, Kerr SR, and Boutilier RG. Physiology and behaviour of free-swimming Atlantic cod (Gadus morhua) facing fluctuating temperature conditions. J Exp Biol 198: 49-60, 1995.

8. Davie PS and Farrell AP. The coronary and luminal circulations of the myocardium of fishes. Can J Zool 69: 1993-2001, 1991.

9. Dejours P. Principles of Comparative Respiratory Physiology. New York: Elsevier, 1975.

10. Farrell AP. A review of cardiac performance in teleost heart: intrinsic and humoral regulation. Can J Zool 62: 523-536, 1984.

11. Farrell AP. Effects of temperature on cardiovascular performance. In: Global Warming: Implications for Fresh Water and Marine Fish, edited by Wood CM and McDonald DG. Cambridge, UK: Cambridge Univ. Press, 1996.

12. Farrell AP. Cardiorespiratory performance in salmonids during exercise at high temperature: insights into cardiovascular design limitations in fishes. Comp Biochem Physiol A 132: 797-810, 2002.

13. Farrell AP and Clutterham SM. On-line venous oxygen tensions in rainbow trout during graded exercise at two acclimation temperatures. $J$ Exp Biol 206: 487-496, 2003.

14. Farrell AP and Jones DR. The Heart. In: Fish Physiology, edited by Hoar WS, Randall DJ, and Farrell AP. San Diego, CA: Academic, 1992, vol. $12 \mathrm{~A}$.

15. Fischer T. The Effects of Climate-Induced Temperature Changes on Cod (Gadus morhua L.): Linking Ecological and Physiological Investigations ( $\mathrm{PhD}$ thesis). Bremen, Germany: Universität Bremen, 2002.

16. Frederich M and Pörtner HO. Oxygen limitation of thermal tolerance defined by cardiac and ventilatory performance in the spider crab, Maja squinado (Decapoda). Am J Physiol Regul Integr Comp Physiol 279: R1531-R1538, 2000.

17. Galli G, Taylor EW, and Wang T. The cardiovascular responses of the freshwater turtle Trachemys scripta to warming and cooling. J Exp Biol 207: 1471-1478, 2004.

18. Haase A. Snapshot FLASH MRI. Applications to T1, T2 and chemicalshift imaging. Magn Reson Med 13: 77-89, 1990.

19. Harper AA, Newton IP, and Watt PW. The effect of temperature on spontaneous action potential discharge of the isolated sinus venosus from winter and summer plaice (Pleuronectes platessa). J Exp Biol 198: 137-140, 1995.

20. Heath AG and Hughes GM. Cardiovascular and respiratory changes during heat stress in rainbow trout (Salmo gairdneri). J Exp Biol 59: 323-338, 1973.

21. Jones FRH. Fish Migration. London: Spottiswood, Ballantyne, 1968.

22. Laevastu T. Marine Climate, Weather, and Fisheries. The Effects of Weather and Climate Changes On Fisheries and Ocean Resources. Oxford: Blackwell Scientific, 1993.

23. Mark FC, Bock C, and Pörtner HO. Oxygen limited thermal tolerance in Antarctic fish investigated by magnetic resonance imaging (MRI) and spectroscopy ( $\left.{ }^{31} \mathrm{P}-\mathrm{MRS}\right)$. Am J Physiol Regul Integr Comp Physiol 283: R1254-R1262, 2002.

24. McDonald DM and Milligan CL. Chemical and physical properties of the blood. In: Fish Physiology, edited by Hoar WS, Randall DJ, and Farrell AP. New York: Academic, 1992, vol. 12.

25. Milligan CL, Graham MS, and Farrell AP. The response of trout red cells to adrenaline during seasonal acclimation and changes in temperature. J Fish Biol 35: 229-236, 1989.

26. O'Brien CM, Fox CJ, Planque B, and Casey J. Climate variability and North Sea cod. Nature 404: 142, 2000.

27. Pettersson $\mathbf{K}$ and Nilsson S. Drug induced changes in cardiovascular parameters in the Atlantic Cod, Gadus morhua. J Comp Physiol 137: 131-138, 1980. 
28. Pogson GH, Mesa KA, and Boutilier RG. Genetic population structure and gene flow in the Atlantic cod Gadus morhua: a comparison of allozyme and RFLP loci. Genetics 139: 375-385, 1995.

29. Pörtner HO. Climate change and temperature-dependent biogeography: oxygen limitation of thermal tolerance in animals. Naturwissenschaften 88: 137-146, 2001.

30. Pörtner HO. Climate variations and the physiological basis of temperature dependent biogeography: systemic to molecular hierarchy of thermal tolerance in animals. Comp Biochem Physiol A 132: 739-761, 2002.

31. Pörtner HO, Berdal B, Blust R, Brix O, Colosimo A, de Wachter B, Giuliani A, Johansen T, Fischer T, Knust R, Lannig G, Naevdal G, Nedenes A, Nyhammer G, Sartoris FJ, Serendero I, Sirabella P, Thorkildsen S, and Zakhartsev M. Climate induced temperature effects on growth performance, fecundity and recruitment in marine fish: developing a hypothesis for cause and effect relationships in Atlantic cod (Gadus morhua) and common eelpout (Zoarces viviparus). Continental Shelf Res 21: 1975-1997, 2001.

32. Pörtner HO, Hardewig I, Sartoris FJ, and van Dijk PLM. Energetic aspects of cold adaptation: critical temperatures in metabolic, ionic and acid-base regulation? In: Cold Ocean Physiology, edited by Pörtner HO and Playle R. Cambridge, UK: Cambridge Univ. Press, 1998.

33. Pörtner HO, Mark FC, and Bock C. Oxygen limited thermal tolerance in fish? Answers obtained by Nuclear Magnetic Resonance techniques. Respir Physiol Neurobiol In press.

34. Pörtner HO, van Dijk PLM, Hardewig I, and Sommer A. Levels of metabolic cold adaptation: tradeoffs in eurythermal and stenothermal ectotherms. In: Antarctic Ecosystems: Models for a Wider Understanding, edited by Davison W and Williams CW. Christchurch, New Zealand: Caxton, 2000.
35. Rinne JN, Holand B, and Sundnes G. Comparison of Heart Rate in Fishes: Cold, Temperate Sea Water Versus Warm, Desert Rivers [Online: http://www-heb.pac.dfo-mpo.gc.ca/congress/2002/Cardiovas/Rinne.pdf" LOCATOR-TYPE $=" U R L ">h t t p: / / w w w-h e b . p a c . d f o-m p o . g c . c a / c o n-$ gress/2002/Cardiovas/Rinne.pdf, 2002].

36. Rose GA. Cod spawning on a migration highway in the north-west Atlantic. Nature 366: 458-461, 1993.

37. Sartoris FJ, Bock C, Serendero I, Lannig G, and Pörtner HO. Temperature dependent changes in energy metabolism, intracellular $\mathrm{pH}$ and blood oxygen tension in the Atlantic cod, Gadus morhua. J Fish Biol 62: 1-15, 2003.

38. Steffensen JF and Farrell AP. Swimming performance, venous oxygen tension and cardiac performance of coronary-ligated rainbow trout, $\mathrm{On}$ corhynchus mykiss, exposed to hypoxia. Comp Biochem Physiol A 119: 585-592, 1998.

39. Tsukuda H, Liu B, and Fujii KI. Pulsation rate and oxygen consumption of isolated hearts of the goldfish, Carassius auratus, acclimated to different temperatures. Comp Biochem Physiol A 82: 281-283, 1985.

40. Van Dijk PLM, Hardewig I, Tesch C, and Pörtner HO. Physiological disturbances at critically high temperatures: a comparison between stenothermal Antarctic and eurythermal temperate eelpouts (Zoarcidae). J Exp Biol 202: 3611-3621, 1999.

41. Webber DM, Boutilier RG, and Kerr SR. Cardiac output as a predictor of metabolic rate in cod Gadus morhua. J Exp Biol 201: 2779-2789, 1998.

42. Yeager DP and Ultsch GR. Physiological regulation and conformation: a BASIC program for the determination of critical points. Physiol Zool 62: 888-907, 1989.

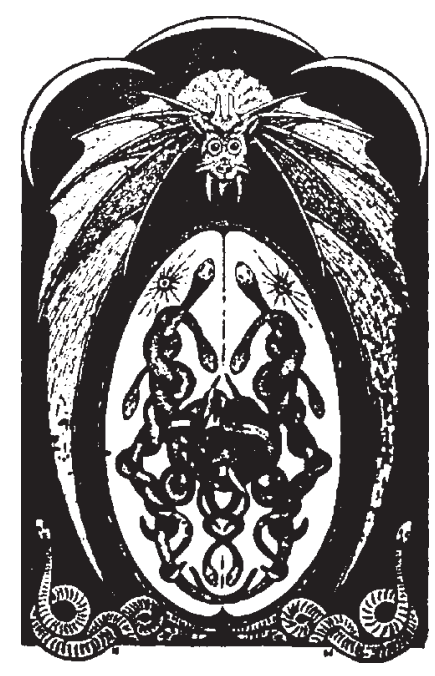

